\title{
Different selection processes, different outcomes? Comparing labor market integration of asylum refugees, resettled refugees and their reunited family members in Finland
}

\author{
Jussi Tervola ${ }^{1,2}$ (D)
}

\section{Correspondence: jussi.tervola@thl.fi \\ ${ }^{1}$ Social Insurance Institution of Finland (Kela), Helsinki, Finland ${ }^{2}$ Finnish Institute for Health and Welfare (THL), P.O. Box 30, 00271 Helsinki, Finland}

\begin{abstract}
This study compares the longitudinal dynamics of labor market integration between asylum refugees, resettled refugees and their reunited family members. The labor market integration of the three refugee groups are compared by using unique longitudinal register data of total refugee population in Finland during 2003-2015. The results show that among males, family reunion migrants integrate faster than asylum refugees and resettled refugees. Contrary to the previous results from Nordic countries, among females, resettled refugees integrate the fastest and family reunion migrants demonstrate the slowest integration. The overall small differences between admission categories are for the large part explained by discrepancies in observed factors such as fertility patterns among females and arrival during recession among males.

Keywords: Migration, Forced migration, Family migration, Labor market integration
\end{abstract}

\section{Introduction}

During the latter half of 2015 an unprecedented number of refugees sought asylum from Western Europe. Approximately 1.3 million asylum seekers, mainly from Syria, Afghanistan and Iraq, dispersed around Europe, most of them filing applications in Germany and Sweden (Eurostat 2016). The situation heated public debate in the receiving countries. Among the concerns was the labor market integration of the refugees and the short- and long-term impact on fiscal budgets (OECD 2017). In the aftermath, some politicians and experts called for reconsideration of humanitarian migration policies. Some debaters suggested putting more emphasis on refugee quotas rather than asylums in order to increase the state's control over the volume and selection of humanitarian migration (see e.g. Hatton 2017).

(c) The Author(s). 2020 Open Access This article is licensed under a Creative Commons Attribution 4.0 International License, which permits use, sharing, adaptation, distribution and reproduction in any medium or format, as long as you give appropriate credit to the original author(s) and the source, provide a link to the Creative Commons licence, and indicate if changes were made. The images or other third party material in this article are included in the article's Creative Commons licence, unless indicated otherwise in a credit line to the material. If material is not included in the article's Creative Commons licence and your intended use is not permitted by statutory regulation or exceeds the permitted use, you will need to obtain permission directly from the copyright holder. To view a copy of this licence, visit http://creativecommons.org/licenses/by/4.0/. 
However, little is known about how different refugee groups, ${ }^{1}$ i.e. asylum refugees, resettled refugees and their reunited family members, are self-selected in a way that would be reflected in their labor market integration. According to economic and sociological migration theory, differences can be expected. Immigration channels, defined by the immigration policies, work as selective filters for arriving immigrants (Borjas 1987). Seeking asylum often requires a costly and risky journey that not everybody is capable or willing to take (Hatton 2017). Resettled refugees in turn are not self-selected to a large extent but are chosen by the officials. Reunited family members of refugees in turn are basically self-selected according to their existing social ties in the destination, which may affect their integration (Aguilera and Massey 2003; Greenwell et al. 1997).

The issue has been studied before but with slightly contradicting results in different contexts. It is known that refugees in general tend to be positively self-selected by having higher human capital than individuals migrated for economic reasons from the same source countries (Aksoy and Poutvaara 2019). Among refugee groups, Bevelander and Pendakur (2014) and Bevelander (2011) find that in Sweden family reunion migrants fare best of the three refugee categories in financial terms. In addition, both in Sweden and Norway asylum refugees seem to integrate faster to labor market than resettled refugees (Bevelander 2011; Bratsberg et al. 2016). The results seem to hold for both genders. However, refugees in Canada demonstrate large gender differences by admission categories. Among males, family reunion migrants integrate fastest but among females, asylum refugees integrate the fastest and family reunion migrants the slowest. Bevelander and Pendakur (2014) argue that the different results in Canada and Sweden may be explained in differences in access to services, which are more universal in Nordic countries.

This study revisits the issue by concentrating on the longitudinal persistence of the differences in another Nordic context, Finland. Most of the previous studies use crosssectional data and therefore they cannot disentangle the longitudinal dynamics of integration from the unobserved differences between migration cohorts (see Borjas 1985; Åslund and Rooth 2007). Bratsberg et al. (2016) use longitudinal data but they do not focus on differences by refugee categories but control it with a constant dummy factor. Longitudinal examination will potentially increase the policy relevance of the results. It may very well be, for example, that the differences between categories are temporary and occur only during the first years of residence, which mitigates their relevance. On the other hand, differences may emerge after a few years of residence and persist, which would make them more critical in terms of economic integration. Also the dynamic patterns may differ by gender.

It should be noted that the exact causal effect of different selection processes on labor market integration is rather impossible to extract from policy effects. Refugees from different channels confront different sets of policies. For example, asylum seekers face lengthy application processes, which may affect their later integration into the destination society (e.g. Hainmueller et al. 2016). Consequently, the study in hand and

\footnotetext{
${ }^{1}$ In this study, the term "refugee" is used to comprise asylum refugees, resettled refugees and their reunited family members. "Asylum refugee" refers to those who have applied for asylum and have been granted a permanent residence permit regardless of being based on asylum in accordance with the 1951 refugee convention, subsidiary protection or so called humanitarian protection. The reunited family members analyzed include mostly spouses because of restricting the analysis to working-age population.
} 
previous studies on the subject (Bevelander and Pendakur 2014; Bevelander 2011; Bratsberg et al. 2016) are more or less descriptive studies that compare the labor market integration of refugees from different categories. In all studies, the observed characteristics are controlled in regression analysis and the potential effect of selection processes is discussed.

The study is located in Finland, characterized by a relatively low level of migration and long distance from typical source countries of refugees. Like other Nordic countries such as Sweden, Finland provides abundant residence-based social security benefits and integration measures (MIPEX ranking 4th in 2014). The main origins of humanitarian migrants in Finland include Iraq, Somalia, Iran and Afghanistan. Main advantage of Finland as a study location is the availability of extensive register data but also the fact that all newly-arrived unemployed migrants with a residence permit have equal access to the integration measures (Sarvimäki and Hämäläinen 2016). This diminishes the potential role of policies in the discrepancies between refugee categories and allows us to concentrate more on the effect of selection processes.

The study is based on administrative register data, which include total population of refugees in Finland arrived during 2001-2014. Their labor market integration is followed through the years 2003-2015. Regression models are used to scrutinize the role of observed characteristics such as gender, age, arrival year, origin country and dwelling area. The unobserved characteristics that cause the possible remaining differences are discussed.

The article is organized as follows. First, the Finnish context is described. Second, theoretical reasons for the potential differences between the admission categories and its gendered patterns are provided. Thereafter the data and methods are presented. Finally, the results are provided and discussed.

\section{The context}

\section{Humanitarian migration to Finland}

The share of migrant population in Finland is relatively low, but its growth since the 1990s has been rapid. In 2015, the share of foreign-born population was 6\% (Statistics Finland 2016). The share of humanitarian migration from total migration is relatively high in European but not by Nordic standards: after 2005, humanitarian migration has constituted less than $10 \%$ of total migration (author's own calculation from the data). The remaining $90 \%$ consists mostly of non-humanitarian family migrants and labor migrants.

Humanitarian migration to Finland has been present since the country's independence in 1917. Just a year after in 1918, the revolution in neighboring Russia brought thousands of refugees to Finland. Later, after World War II, when Finland ceded its eastern areas to the Soviet Union, large numbers of internally displaced persons arrived in Finland (Välimäki 2019).

Finland received its first official refugees in the 1970s, a few hundred political refugees from Chile and later from Vietnam. Only at the start of the 1990s, Finland started to receive substantial numbers, more than a thousand refugees migrant per year, from countries such as Somalia and the former Yugoslavia. By the end of the decade, humanitarian migration waned. At the turn of the millennium, the trend turned again to 
an increase, mainly by refugees from Iraq, Somalia and Afghanistan (Finnish immigration service 2019).

In 2015, the number of filed asylum applications reached new records 32,500 individuals), which is almost ninefold compared to the previous year. However, only a minority of newcomers was eventually granted a residence permit. The high inflow also resulted in tightened criteria for residence permit: before the crisis in $2015,16 \%$ of the permit decisions for international protection were negative, whereas in 2016 the rate was $51 \%$. The clear majority of claimants originated from Iraq, whereas in many other European countries Syrians were the principal group. The numbers of asylum seekers waned quickly close to the previous levels in 2016. The number of resettled refugees and family reunion migrants has remained relatively stable throughout the 2000s (Finnish Immigration Service 2019.)

This study pertains to humanitarian migrants and their reunited family members before the inflow of 2015. The study population consists of refugees and their family members who were granted residence permit to Finland between the years 2001 and 2014 and have resided in the country at least until 2015. These approximately 15,000 migrants originate mostly from Iraq, Somalia, Afghanistan and Iran. 40\% of the study population arrived as asylum seekers. Both resettled refugees and family reunion migrants constitute $30 \%$ of the study population (see Chapter 4 ).

\section{Humanitarian policies in Finland}

Whereas the resettlement policy is mainly determined nationally, asylum policy is based on international treaties, the most significant being the refugee convention from 1951. The convention has been ratified by the majority of Western countries, including Finland. It declares a person's right to seek asylum and the state's responsibility to grant asylum in case of "well-founded fear for being persecuted for reasons of race, religion, nationality, membership of a particular social group or political opinion" (UNHCR 2018). The convention does not strictly pertain to individuals fleeing from war. Nonetheless, the extended criteria for refugee reception, included in the European Union Directive 2004/83/EC, requires granting subsidiary protection to war refugees.

In addition to asylum and subsidiary protection, a few hundred refugees in Finland has been granted residence permit with a third permit type called humanitarian protection. This type was used nationally until 2016 if the criteria for asylum or subsidiary protection were not fulfilled but the claimant could not return to his origin because of security reasons (Finnish immigration service 2016). In this study, "asylum refugee" refers to those who have applied for asylum and have been granted a permanent residence permit either based on asylum in accordance with the 1951 refugee convention, subsidiary protection or humanitarian protection.

Resettled refugees are selected directly from the source area to Finland in cooperation with UNHCR. The number of refugees received is regulated through a quota determined by the government of Finland. The quota has been 750 individuals until 2013. In 2014, the quota was raised to 1050, but in 2017 it was cut back to 750 individuals (Finnish Immigration Service 2018). The process goes as follows: first, UNHCR suggests potential individuals for selection. They are later interviewed by the representatives of the Finnish government. Individuals classified as "emergency cases" (10\% of the quota) are chosen 
without being interviewed (Finnish Ministry of Interior 2020). The main criterion for the selection is the same as for all humanitarian migration: the need for international protection. In addition, according to the Finnish Ministry of Interior (2020), Finland gives priority to vulnerable groups, that is, whole families and women in difficult situations such as widows and single parents.

The third channel investigated in this study is family reunion migration. According to the Finnish Aliens Act (2004), it concerns close family members such as a child, spouse or parent, but other relatives can also be regarded as family members in special cases. However, because of concentrating to working-age population, the focus in this study is on the migration of spouses from refugee origins. Until 2016 family reunion migrants of refugees in Finland were exempted from income-testing. Since 2016 income-testing is applied to the family reunion of refugees with subsidiary protection status.

\section{Integration and resettlement policies in Finland}

Finland is typically categorized as a Nordic welfare state. One of its features is that the eligibility to different social benefits is residence-based rather than depending on contribution history or citizenship of the applicant (Sainsbury 2006). Hence, all refugees receive access to benefits once they receive a residence permit to Finland.

The integration policies have been noted to play a significant role in the effectiveness of integration (Sarvimäki and Hämäläinen 2016). Since 1999, Finland has incorporated legislation that requires officials to draw individual integration plans for all newly arrived migrants who are registered as unemployed or recipients of social assistance. The eligibility and type of integration measures are independent from admission categories, and the design of the measure has been similar during the study period of 2003 to 2014. The integration plan is determined on the individual level in cooperation with migrant and employment officials. The plan entails measures that aim to support immigrants' opportunity to acquire a sufficient command of Finnish (or Swedish) and other knowledge and skills required in Finnish society and working life (Act on the Integration of Immigrants and Reception of Asylum Seekers 1999).

In addition to integration policies, resettled refugees and asylum refugees are subject to so called dispersal policies. The municipalities in Finland have the autonomy to determine the number of refugees they are ready to receive. The receipt of refugees requires the municipality to arrange dwelling and integration services for the refugees. The state gives incentives for the receipt by compensating a lump sum per refugee to the municipality and some running expenses. Resettled refugees and asylum refugees, when granted a residence permit, are appointed randomly to a municipality on the basis of available slots. However, asylum refugees may and often state their preference for municipality of residence, which is fulfilled if there are available slots. They may also move independently to any municipality with the some support from the reception center (Sjöblom-Immala 2016). In a survey, only two out of five asylum refugees planned to spend at least a year in the region that they were appointed in after receiving a residence permit. The mobility of asylum refugees is enhanced by the social networks tied during application process. (Jauhiainen 2017). 
Urban areas typically provide more extensive job prospects. Therefore, refugees in Finland tend to move to urban areas even though they are dispersed all over the Finnish territory, both rural and urban (Ahlgren-Leinvuo 2005; Jauhiainen 2017). Family reunion migrants in turn join their refugee family members after a delay and therefore are likely to be more concentrated in urban areas right from the start of their residence.

\section{Finnish labor markets}

Finnish labor markets are regulated through collective labor agreements. Therefore, no national minimum wages exits but they are bargained separately by different trade unions. The collective bargaining has resulted in a high level of job security but also inflexibility of labor markets, which may hamper especially the recruitment of immigrants with lower human capital than native-borns (Kahn 2012). Discrimination based on one's origin or gender, for example, is illegal and these characteristics should be in principal disregarded in processes such as wage-setting and recruitment. However, job application studies have observed discrimination against certain ethnicities (Liebkind et al. 2016).

Undeclared work, typically pronounced among immigrants (e.g. Vasta 2004), is not as common in Finland (13\% of GDP) as in EU countries on average (18\% of GDP) (Schneider and Kearney 2013). Typically to Nordic countries, both men and women participate in labor markets at high levels in Finland. At the same time occupations are highly segregated by gender (Jarman et al. 2012). Women are concentrated in care, education and service sector whereas men are over-represented among construction, logistics and industry sector (Statistics Finland 2018).

As in other Nordic countries, immigrants in Finland have wider gender gaps in labor market participation than native-borns (Eurostat 2020). The employment rates of immigrants vary drastically by origin country, immigrants from Middle East and East Africa having the lowest and immigrants from Europe having the highest rates (Busk et al. 2016).

\section{Potential role of the admission category}

\section{General}

There are two main reasons why asylum refugees, resettled refugees and family reunion migrants would integrate at a different rate: 1 ) the channels select different kinds of individuals or 2) the individuals from different channels are confronted with a different set of local policies.

According to the economic theory, differences in selection can be expected. Classic economic migration theory (Borjas 1987) regards migration as a rational investment which is determined by weighing the expected costs and benefits of migration. If benefits exceed the costs, it pays off to migrate. Here, costs should be understood, not only in monetary, but also in more abstract terms. They can entail the risk of fatality or rejection of the residence application. The anticipated gains are highly dependent of acquired skills, which, according to the theory, automatically leads to a non-random selection from the skill distribution of the source country. 
In the case of humanitarian migration, the highest costs and risks are carried out by asylum refugees (e.g. Hatton 2017). Coming to northern Europe, many asylum refugees take a hazardous maritime route over the Mediterranean, followed by a trip through land, usually with the help of smuggler transit. The migration costs are further increased by the probability of rejection. For the studied migration cohort years 20012014, the odds of having positive decision to asylum application was 1:2 (Finnish Immigration Service 2019). The high costs of migration should be met with high anticipated gains for the migration to pay off. This leads to the expectation of a positive selfselection of asylum refugees, i.e. their labor market integration would be faster than among the resettled refugees.

In addition to positive self-selection, asylum refugees may also be negatively selfselected for Finland due to the welfare magnet, a term first coined by Borjas (1999). That is, the relatively generous Finnish welfare system may attract especially low-skilled migrants, who are likely to benefit from extensive welfare provision. Although being a popular argument in political discourse, the evidence is scarce (see e.g. Barrett and McCarthy 2008). Birgier et al. (2016) shows some evidence of negative self-selection of refugees to Sweden as compared to United States and Israel. Authors argue that the results can be explained by the fact that Sweden had least restrictive migration policies, most generous welfare system and the lowest levels of returns to skills.

Resettled refugees are not generally speaking self-selected but selected by officials of UNHCR and national governments. The selection is not random. The Finnish Ministry of Interior states that vulnerable groups such as families and single women are emphasized when selecting the quota members from the camps (Finnish Ministry of Interior 2020). However, the selection process has not been documented or verified.

Family reunion migrants, and perhaps asylum refugees to some extent, are selfselected on the basis of existing social ties to the destination. The existing social ties in the host country can potentially facilitate their labor market integration compared to the resettled refugees (Bevelander and Pendakur 2014). Vast sociological literature exists how social capital advance labor market integration, especially among immigrants, by providing inside contacts and greater information about the opportunities (Portes and Sensenbrenner 1993; Aguilera and Massey 2003; Ahmad 2015). Especially bridging social capital with outward-looking and inter-ethnic contacts seems to be useful for immigrants' employment in contrast to inward-looking bonding social capital which reinforces exclusive identities (Lancee 2010). The social ties make job search more efficient resulting in higher probability of employment, higher wages and better job quality (Aguilera and Massey 2003). Strong social ties can potentially facilitate labor market integration also by increasing the sense of belonging (Boccagni and Baldassar 2015). The reunion of a family, for example, is likely to benefit, not only the family reunion migrant, but also the family members that have migrated earlier to the destination.

In addition to selection-driven differences, labor market differences between the channels may stem from different policies. For instance, a long asylum application process or a long waiting time at a refugee camp may have an impact on later integration in the destination. Using Swiss data, Hainmueller et al. (2016) show that a lengthy asylum process has a deterrent effect on subsequent employment. A study from Sweden (Bevelander and Pendakur 2009) had a contradictory result, showing that 
longer waiting periods facilitate asylum refugees' later employment. The cause of these contradictory results is somewhat unclear; but it seems plausible that if asylum refugees work during the asylum process, it will facilitate their later integration once they receive a residence permit. Like in the majority of European countries, asylum seekers in Finland are allowed to work 3-6 months after arrival.

The dispersal policy may also create differences in labor market integration between admission categories. Asylum refugees and especially family reunion migrants are not dispersed to rural areas at same extent than resettled refugees (see Chapter 2.3). Because urban areas typically provide more extensive job prospects, dispersal policy may hamper labor market integration of resettled refugees especially (Damm and Rosholm 2010).

\section{Differences by gender}

The refugee category is strongly associated with gender. Asylum refugees are more often men, which probably reflects the risk-taking patterns and consequently reunited family members are clearly more often women (e.g. Cerrutti and Massey 2001). Women are over-represented among resettled refugees, which is also the outspoken priority of Finnish government (Finnish Ministry of Interior 2020).

Gender is also associated strongly with labor market integration to the host society. In many countries, including Finland, female immigrants demonstrate slower labor market integration than men (Cerrutti and Massey 2001; Sarvimäki 2017). This is partly related to the gender roles that stem from origin countries (Antecol 2000) but also fertility patterns that are known to be strongly associated with migration (Andersson 2004). Especially in the case of spousal reunion, the probability of childbearing is high in the beginning of residence (Mussino and Strozza 2012). Therefore, fertility is likely to affect the labor market integration of female migrants, and especially family reunion migrants. Men's labor market participation is not presumably hindered due to childbearing because fathers' use of parental leave is at low levels in Finland, especially when originating from typical origins of refugees (Tervola et al. 2017).

In addition, the economic gains of social ties among immigrants have been observed to differ by gender, men having greater benefits (Greenwell et al. 1997; Aguilera and Massey 2003). Strong familial social ties may even hinder women's labor market integration if their labor market participation is not socially supported due to the family or cultural practices (Greenwell et al. 1997; Pehkonen 2006; Zontini 2010). This may possibly hamper female family reunion migrants' integration as compared to resettled refugees and asylum refugees.

All of the issues stated above can create gendered differences in the integration of refugees from different admission categories. Because some of the factors have effects in opposite directions and the size of the effect of each factor is unknown, it is hard to argue about the total expected differences. The best study hypothesis may be to anticipate similar results to those found in previous Nordic studies (Bevelander 2011; Bratsberg et al. 2016): Family reunion migrants integrate into labor markets the fastest, as they have the strongest existing ties in the country. Asylum refugees become employed faster than resettled refugees, due to positive self-selection and perhaps existing ties for some. Like in the study of Bevelander (2011), the pattern is expected to be similar for 
both genders. The differences between admission categories are expected to diminish but also endure in the controlled model because of the different selection process, which is probably not fully caught by observed characteristics.

\section{Data}

The analysis is based on individual-level longitudinal data from Finland. Data are compiled from multiple administrative registers such as the population register, the tax register and the registers of the social insurance institution. The data include information on taxable earnings, unemployment benefits and child care benefits as well as demographic information on age, gender, country of birth, migration year, dwelling area and marital status.

The study population contains the total working-age population (ages 25-60) of humanitarian and family reunion migrants who migrated to Finland during 2001-2014. Their labor market outcomes are followed through the years 2003-2015, one observation per year. The length of the follow-up ranges from 1 to 13 years, depending on the migration cohort. Migrants who do not fall in the age range of 25-60 in a particular year are considered as missing observations.

While the data is extensive by its total population and longitudinal length, it has drawbacks. First, we do not observe the earnings of asylum refugees before they receive their residence permit. Consequently, pre-permit work may boost labor market integration of asylum refugees compared to resettled refugees and family reunion migrants. Second, we do not observe undeclared work. Third, the data lack the exact spells of employment and unemployment. Instead of spells, they include the annual sums of different (taxable) income items: e.g. earnings, unemployment benefits and child care benefits. This somewhat limits the choice for an outcome variable. To get a more comprehensive picture, the three most common labor market states are analyzed separately: employment, unemployment and being on child care leave.

The first outcome, employment, is analyzed through annual earnings, zero earnings included. They entail all wage and self-employment income during the year. Earnings reflect two dimensions of labor market integration: the length of the employment during the year as well as the wage level.

The second outcome, the incidence of unemployment, is analyzed through a dichotomous indicator of whether or not there was unemployment benefit income during the year. The annual sum of received unemployment benefits is not used because it does not reflect integration straightforwardly: high earnings-related unemployment benefits can also indicate high prior wages and therefore a higher level of integration. It should be noted that Finland also provides flat-rate unemployment benefits that do not require any prior contribution or work history. The flat-rate unemployment benefits are also paid during the integration program, which is why the receipt of benefits is very common among refugees during the first years of residence. The only general requirements are being 17 to 64 years of age and actively looking for work.

The third outcome is the incidence of child care. Similar to unemployment, the annual sums of (earnings-related) child care benefits do not reflect integration straightforwardly. That is why the incidence of child care is analyzed with the annual dichotomous indicator of whether or not benefits are received. The binary measure of being on child care leave is based on the receipt of parental benefits as well as cash-for- 
care (CFC) benefits during the year. In Finland, the parental benefits can be paid until the child is approximately 9 months old. If the parent has no prior earnings, a flat-rate benefit is paid. Around $90 \%$ of families prolong their care leave with CFC, which is a flat-rate benefit that can be paid until the youngest child turns 3 years old (see e.g. Duvander and Ellingsæter 2016). The use of CFC is pronounced among immigrant families (Tervola 2015).

The analysis focusses on individuals coming from typical refugee origins, which are defined as those where humanitarian migration constitutes more than $15 \%$ of total migration. For estimation purposes, only individuals from origins where all three studied admission categories are present are included. The list of included countries and number of observations by gender are shown in Table 2 in Appendix.

The information on admission category is based on the registration by the social security officials when migrants apply for social insurance coverage from the state. The information is missing for $2 \%$ of migrants from typical refugee origins due to not having applied for the coverage by August 2016, when the data were compiled. Additionally, where coverage was applied for, the admission category was not registered due to unknown reasons for $4 \%$ of migrants. These migrants (mostly from former Yugoslavia) are excluded from the study population.

Migrant populations are usually subject to non-random onward and return migration (e.g. Dustmann and Görlach 2016). Previous studies have shown that poor economic attachment to the host country increases the risk of return and onward migration (e.g. Edin et al. 2000; Monti 2019). In this study, the migrants who emigrated during the follow-up are excluded from the analysis. ${ }^{2}$ Consequently, the analysis concentrates on migrants who have decided to settle, which may lead to a more positive picture of the integration.

All in all, the final study population consists of 14,766 individuals, with an average follow-up of 5.5 years. As seen from Table 1, the most populous category among men is asylum refugees (52\%) and family reunion migrants are the smallest (22\%). Among women, family reunion migrants constitute the largest category (40\%), whereas asylum refugees are the smallest (26\%). Resettled refugees are slightly more often women (52\%) than men (48\%), reflecting the outspoken policy to emphasize e.g. single women. However, the difference is very small.

Different admission categories demonstrate clear difference in observed characteristics. Family reunion migrants are slightly younger on average than asylum refugees or resettled refugees. Asylum refugees stand out from the other two categories, being concentrated more in the recent migration cohorts, whereas resettled refugees and family reunion migrants have come in a steadier flow. Family reunion migrants have toddlers in their households in the beginning of their residence more often than do individuals in other admission categories.

Single parenthood is prevalent especially among women. Around $5 \%$ of men and a fifth of women are single parents in their first year of residence. The respective proportions rise to $9 \%$ of men and $24 \%$ of women in the tenth year. Among nearly all refugee

${ }^{2}$ Emigration is often left unregistered. In order to complement the official emigration registration, we exclude those migrants who have no income for 3 years in row (benefits or salary). The rate of onward migration among the studied population was approximately $5 \%$. Family reunion migrants had highest rate, around $8 \%$. 
Table 1 Descriptive statistics of the study population

\begin{tabular}{|c|c|c|c|c|c|c|}
\hline & \multicolumn{3}{|l|}{ Males } & \multicolumn{3}{|l|}{ Females } \\
\hline & $\begin{array}{l}\text { Resettled } \\
\text { refugees }\end{array}$ & $\begin{array}{l}\text { Asylum } \\
\text { refugees }\end{array}$ & $\begin{array}{l}\text { Family reunion } \\
\text { migrants }\end{array}$ & $\begin{array}{l}\text { Resettled } \\
\text { refugees }\end{array}$ & $\begin{array}{l}\text { Asylum } \\
\text { refugees }\end{array}$ & $\begin{array}{l}\text { Family reunion } \\
\text { migrants }\end{array}$ \\
\hline $\bar{N}$ & 2059 & 4148 & 1773 & 2245 & 1794 & 2747 \\
\hline$\%$ by gender & 26 & 52 & 22 & 33 & 26 & 40 \\
\hline \multicolumn{7}{|l|}{ Age at arrival, $\%$} \\
\hline $16-24$ & 24 & 26 & 29 & 23 & 22 & 35 \\
\hline $25-34$ & 33 & 48 & 45 & 36 & 44 & 41 \\
\hline $35-44$ & 28 & 19 & 17 & 26 & 21 & 17 \\
\hline $45+$ & 16 & 8 & 9 & 16 & 12 & 7 \\
\hline \multicolumn{7}{|l|}{ Migration cohort, \% } \\
\hline $2001-2003$ & 22 & 6 & 17 & 19 & 11 & 17 \\
\hline 2004-2006 & 25 & 7 & 20 & 22 & 10 & 17 \\
\hline 2007-2009 & 23 & 26 & 25 & 23 & 22 & 25 \\
\hline 2010-2014 & 30 & 61 & 38 & 37 & 58 & 41 \\
\hline $\begin{array}{l}\text { Toddlers in family during the first } 3 \\
\text { years of residence, } \%\end{array}$ & 36 & 17 & 51 & 34 & 38 & 55 \\
\hline \multicolumn{7}{|l|}{ Single parent, $\%$} \\
\hline First year & 3 & 5 & 6 & 26 & 24 & 8 \\
\hline 10th year & 8 & 12 & 10 & 24 & 33 & 21 \\
\hline \multicolumn{7}{|l|}{ Local unemployment, \% } \\
\hline First year & 12 & 12 & 11 & 13 & 12 & 11 \\
\hline 10th year & 12 & 12 & 12 & 12 & 11 & 11 \\
\hline
\end{tabular}

The information by duration of stay is calculated among the applicable migration cohorts

channels, the incidence of single parenthood becomes more common as the stay grows longer.

Lastly, the average municipal unemployment rates, which reflect local labor demand to some extent, are on the same level on the first and tenth years of residence. However, the figures hide the annual changes during the study period. As seen from Fig. 1, the global financial crisis hit Finland in 2008, and consequently the unemployment rates increased in subsequent years. Simultaneously the flow of asylum refugees increased significantly, meaning that the potential scarring effect of recession (see Åslund and Rooth 2007) may especially affect asylum refugees during the study period.

\section{Empirical strategy}

The integration patterns are analyzed through regression models. Models are run with and without controls to see how much the difference stems from observed heterogeneity e.g. in demographic variables. The analysis is conducted for both genders separately. However, participation in child care schemes is analyzed only among women, because immigrant fathers in Finland use child care benefits only marginally (Tervola et al. 2017). The estimation equation of labor market integration is defined as follows:

$$
y_{i t}=\alpha_{i}+c_{j}+\mathbf{Y S M}_{i t} \mathbf{\alpha}+c_{j} \times \mathbf{Y S M}_{i t} \boldsymbol{\beta}+\left(\mathbf{X}_{i t} \boldsymbol{\delta}+\theta u_{r t}+l_{m}+b_{k}\right)+\varepsilon_{i t},
$$

where $y_{i t}$ is the outcome of interest for individual $i$ at year $t . \alpha_{i}$ is an individual random effect, which accounts for individual-level correlation between different 


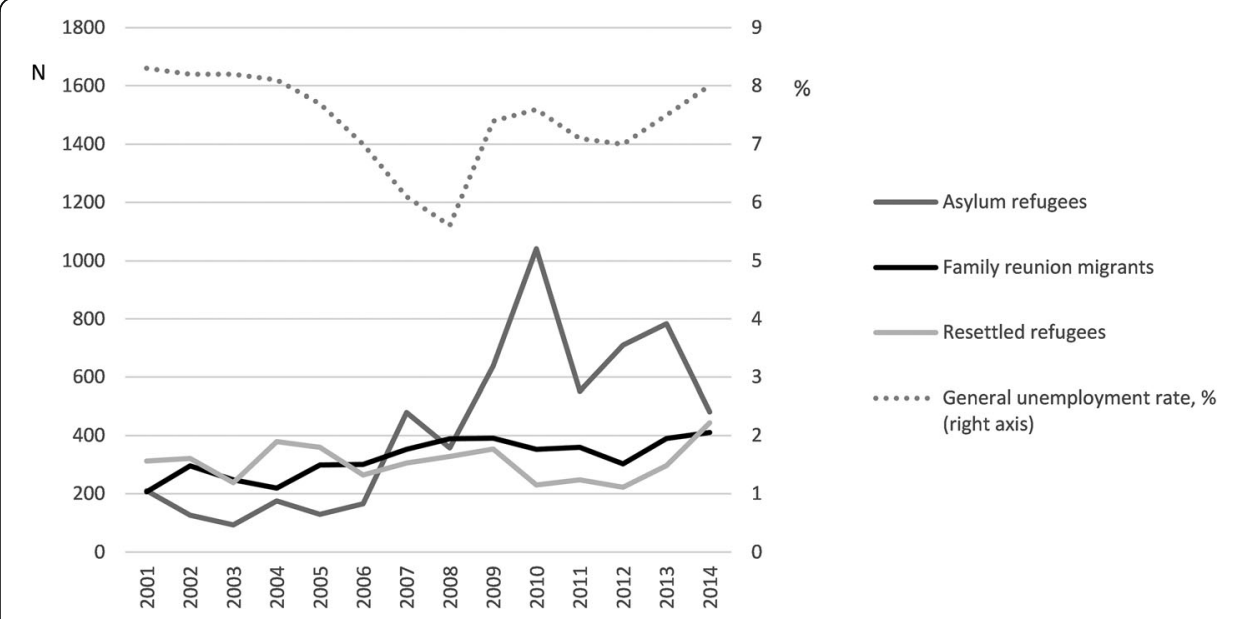

Fig. 1 The frequencies of refugee categories by migration year juxtaposed with general unemployment rate in Finland. Source: frequencies from the data and employment rate from the Labor Force Survey (Statistics Finland 2019a)

years. The random effects with an autocorrelated covariance structure are estimated through the generalized least squares method, as it is available in Stata version 13.0. $c_{j}$ is a dummy variable reflecting the refugee category (asylum refugee, resettled refugee, family reunion migrant). $\mathbf{Y S M}_{i t}$ is a third order polynomial on the number of years the individual has resided in Finland. The third order polynomial was chosen to smooth the integration slopes. Year dummies were also tested: they end up in very similar slopes, however, with wider confidence intervals and less efficient estimation. Hence parametrization was preferred. Years since migration are interacted with refugee category $c_{j}$ to allow varying patterns by category.

$\mathbf{X}_{i t}$ is a vector of time-varying individual characteristics: age, number of children below 8 years of age in the household and single parenthood. $u_{r t}$ is the regional unemployment rate. $l_{m}$ and $b_{k}$ are migration year and origin country fixed effects. Age is controlled because it is known to determine employment probability. Typically individuals close to retirement age have a harder time finding a job. The number of children in the household is likely to be associated with the employment patterns in the household. Prior literature suggests a decrease in the employment probability of women, but an increase in that of men (e.g. Lundberg and Rose 2000). The regional unemployment rate by municipality reflects the local labor demand and, more generally, the economic cycle. As the share of migrants is low in every municipality (maximum $8 \%$ in the capital city), the general unemployment rate mostly reflects the labor market situation of local natives. Controlling for local unemployment will level out the differences in geographical distribution due to e.g. different resettlement policies. It should be noted, however, that it does not take into account for the possible long-standing effects of dispersal policies (see Damm and Rosholm 2010).

Migration year aims to catch the variation in employment prospects of migration cohorts due to the scarring effect (Åslund and Rooth 2007). It may also 
control the variation in the composition of migrant cohorts by unobserved characteristics, e.g. education level. Human capital or educational levels could not be controlled because register data of foreign degrees is of very poor quality (Saarela and Weber 2017). Therefore, variation in human capital remains uncontrolled. However, origin-level fixed effects are added to control for some unobserved heterogeneity in skill and education composition and transferability, which are typically some of the main predictors of labor market integration for immigrants (e.g. Borjas 1987).

\section{Results}

\section{The earnings}

Figure 2 presents the uncontrolled and controlled predictions of mean annual earnings, including zeros, by admission category. We can see that among males, family reunion migrants' earnings seem to increase at a much higher rate than for asylum refugees and resettled refugees. The difference from the other admission categories diminishes with years since migration but loses statistical significance only after 12 years of residence. Asylum refugees have slightly higher initial earnings than resettled refugees do, which may indicate slight positive selection or initiated labor market integration during the asylum process. However, the earnings levels of the two converge quickly, and resettled refugees overtake asylum refugees' earnings, albeit without statistical significance.

Controlling for confounding factors diminishes the gaps between the three categories. Closer examination (not shown) reveals that it is mostly migration cohort that diminishes the gap between asylum refugees and family reunion migrants. In line with scarring effect theory (Åslund and Rooth 2007), the weakest predicted earnings are for those who arrived during the recession years, especially in 2009 and 2010 (see Table 3 in Appendix). These are also the cohorts where asylum refugees are clearly overrepresented (Fig. 1), and hence controlling for it diminishes the gaps.

Moreover, the gap between resettled refugees and other categories is diminished by controlling for the age distribution. Resettled refugee men have arrived at older ages on average, which is associated with lower earnings. However, even after the abovementioned controls, the gaps remain statistically significant until the eleventh year of residence.

Among females, the earning curves of refugees in different categories demonstrate almost a mirror image of that of males. The differences between admission categories are negligible at the beginning but start to become significant after 6 years of residence. Then, it is the resettled refugees that fare better than the other two categories. Family reunion migrants have the lowest earnings. The gaps among females are only slightly diminished when the controls are added. Closer examination reveals that the effective controls for females are the number of children and the origin dummies. Importantly, the findings for both males and females seem somewhat robust through different migration cohorts (see Figure 5 in Appendix). This suggests that the findings can be generalized through time. 


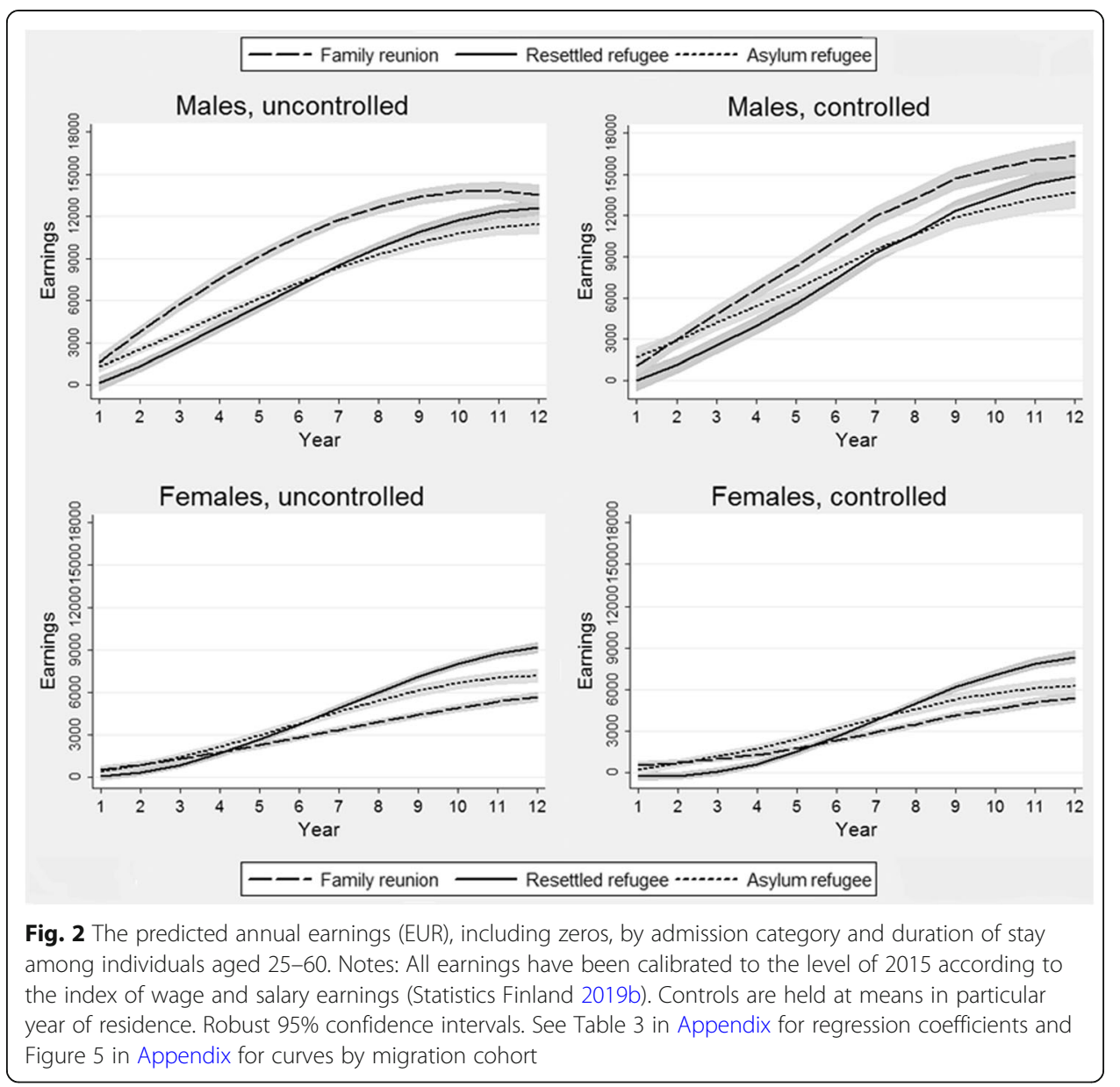

\section{The unemployment rates}

The results for unemployment rates-or more correctly the share of working-age population that received unemployment benefits during the year-mostly mirror the results of earnings (see Fig. 3). Among males, family reunion migrants have the lowest unemployment rates, and they converge to the other categories after 9 years of residence. Again, it is the discrepancies in migration year and age distribution that explain the differences. Unlike for earnings, the gaps are completely abolished after including controls.

Females demonstrate more decisive differences in unemployment rates than in earnings. The order of the categories resembles that of males, but the gaps are wider and more persistent through time. The family reunion migrants have the lowest unemployment rate at the beginning of residence, but the situation turns upside down at the end of the follow-up when their unemployment rates even start to increase.

The discrepancies between employment and unemployment patterns of females suggest that their employment is not substituted only with unemployment but something else, most probably child care. This is also implied by the fact that family reunion migrants most often have toddlers in their families (Table 1). 


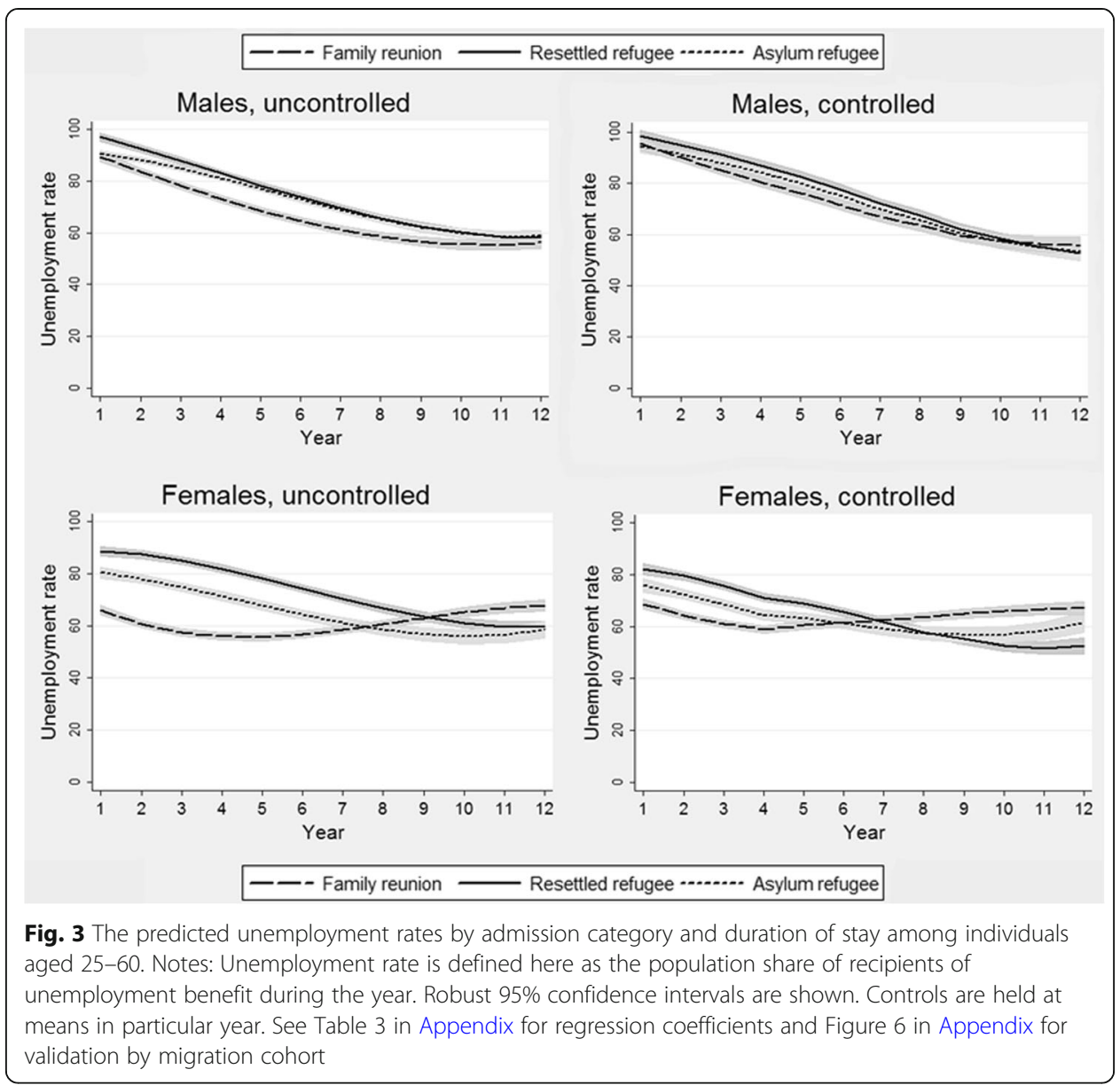

Indeed, controlling for number of children clearly diminishes the gaps between family reunion migrants and the other two categories, but it does not abolish the gaps completely. Nevertheless, it may very well be that what we see is the lagged effect of children: the slow increase of unemployment rate could be caused by mothers entering the labor market from child care. Further analysis shows that including the lagged number of toddlers in the family has a strong positive association with the unemployment rate (not shown). However, it does not further diminish the gaps between categories.

\section{The take-up of child care benefits}

Mothers' absence from labor force due to child care can be deduced through the receipt of parental benefits and cash-for-care (CFC). In the following, the receipt of care benefits is analyzed among females from different admission categories. The results are likely to reflect differences in fertility patterns but possibly also in the length of benefit spells.

Family reunion migrants are clearly over-presented in the recipients of care benefits during the first 10 years of residence (Fig. 4 left side). When number of children is controlled for, the differences in receipt of benefits abolish almost completely. Only 


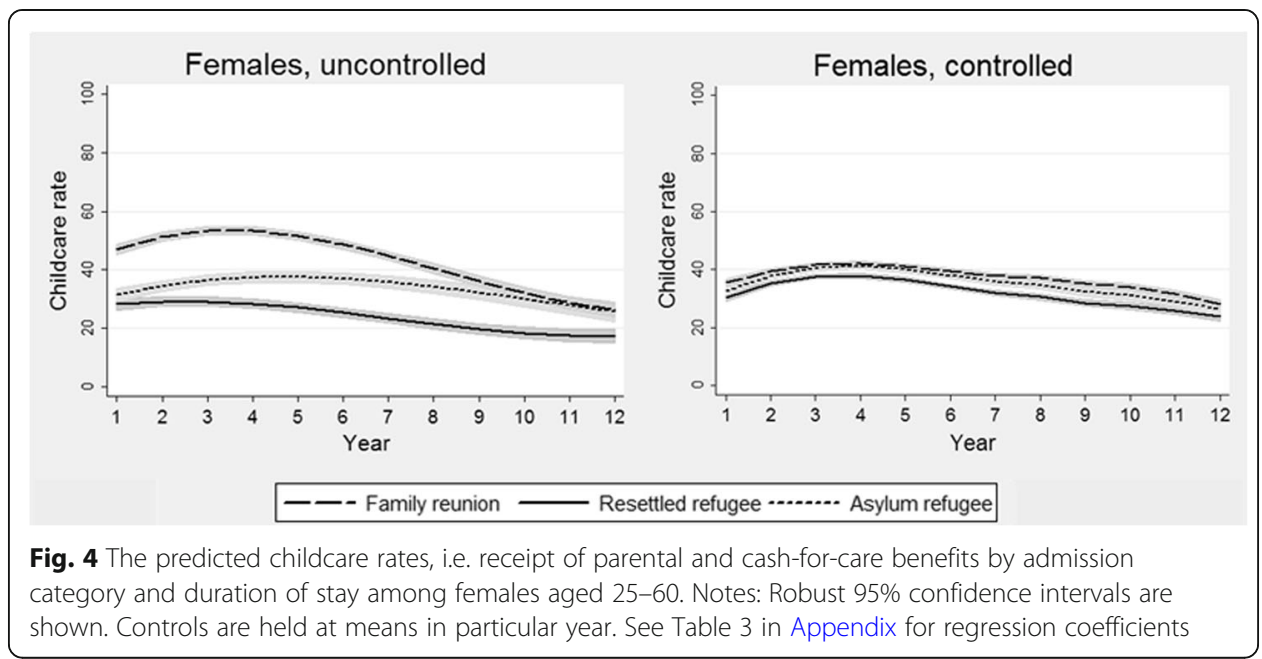

resettled refugees seem to have slightly lower child care rates than the other two categories, which implies that resettled refugees may have slightly shorter care spells per child.

\section{Discussion}

This research examined the role of admission category in the labor market integration of humanitarian migrants. The analysis concentrated on the integration patterns of resettled refugees, asylum refugees and family reunion migrants in the Finnish context. The central question was whether the different selection processes of the three refugee groups cause discrepancies in their employment trajectories. Following previous results from Nordic countries (Bevelander 2011), the study hypothesis asserted that family reunion migrants integrate at the fastest rate into the labor markets, perhaps due to existing ties in the country, then followed by asylum refugees and resettled refugees. The pattern was expected to be similar for both genders.

Among males, the hypothesis holds. Reunited family members seem to integrate at the fastest rate. Their integration is likely boosted by the earlier arrived family members who have already started their integration process in the destination. However, not much difference exists between asylum refugees and resettled refugees, which speaks against the expected positive self-selection of asylum refugees.

The gaps between categories of males diminish as the duration of stay grows longer. The discrepancies in labor market integration between the categories are also to a large extent explained through the observed characteristics. Asylum refugees' integration was hindered because many of them arrived at the time of recession, reflecting the so called scarring effect of initial labor market condition (Åslund and Rooth 2007). Resettled refugee males were older on average than asylum refugees and family reunion migrants, which explained some of the discrepancies in labor market integration between the groups.

Contrary to the hypothesis, the patterns among females differ clearly from that of males. Among females, resettled refugees integrate fastest into the labor markets, 
whereas reunited family members integrate the slowest. However, the differences in earnings appear only after 6 years of residence. The results contradict the previous results from other Nordic countries but are in line with previous results from Canada (Bevelander and Pendakur 2014).

It is unclear, why previous Nordic studies have not found gender differences in the association between admission category and labor market integration. Bevelander and Pendakur (2014) do not either discuss the potential reasons for their different results in Sweden and Canada. In Finland, the result among females is explained mostly by the discrepancies in fertility patterns of refugees from different admission categories. Based on prior demographic literature (Mussino and Strozza 2012), it is not surprising that female family reunion migrants have higher propensity of absence from labor market due to child care leave than refugees in other categories, especially in the beginning of the residence but also after 12 years since migration. This clearly has an effect on their labor market integration through the 12 year follow-up and perhaps permanently. Many resettled refugee women, in turn, have children born before the migration, reflecting the preference of the Finnish government for entire families and single mothers in selecting resettled refugees. This difference in selection benefits resettled refugee women's integration. However, it may have different implications for the child's integration if he or she has undergone traumatic events in the origin (see e.g. Lunneblad 2017).

The study was located in Finland characterized with small immigrant population, highly regulated labor markets and abundant and universal provision of integration policies and care leave. To some extent, the results are bound to be restricted to the context. For example, if admission categories differ in their access to integration measures, like in Canada, it is likely to change the results. The relatively small refugee population in Finland may also mitigate the effect of social networks on employment as compared to Sweden and Canada.

Despite concentrating on a single country, this study was the first to study the longitudinal integration patterns by admission categories of refugees and their families. In addition to integration in earnings and unemployment, child care patterns were included in the analysis. The research data were unique in terms of its total population, lengthy follow-up and administrative register information on humanitarian groups. However it had its drawbacks: Educational attainment could not be controlled, which is general problem in using register data for migrants. Also informal employment was not observed. Thirdly, the prevalence of unemployment and child care leave was not measured optimally by spells but annual dichotomous indicators.

The study was partly motivated by the aftermath of 2015, when some debaters suggested putting more emphasis on refugee quotas rather than asylums in order to increase the state's control over the volume and selection of humanitarian migration. All in all, similarly to previous studies, the differences between refugee categories found in this study are relatively small. A large part of the differences could be explained by fertility patterns and arrival year. In future, evidence of labor market dynamics from other contexts would be crucial to add to the generalization of the results. Also, comparing the persistence of child penalty of recent humanitarian migrants to other migrants and native population would provide essential information that is currently lacking. 


\section{Appendix}

Table 2 The data frequencies by gender, admission category and the country of birth

\begin{tabular}{|c|c|c|c|c|c|c|c|}
\hline \multirow[t]{2}{*}{ Origin } & \multicolumn{3}{|l|}{ Males } & \multicolumn{3}{|l|}{ Females } & \multirow[t]{2}{*}{ Total } \\
\hline & $\begin{array}{l}\text { Resettled } \\
\text { refugees }\end{array}$ & $\begin{array}{l}\text { Asylum } \\
\text { refugees }\end{array}$ & $\begin{array}{l}\text { Family reunion } \\
\text { migrants }\end{array}$ & $\begin{array}{l}\text { Resettled } \\
\text { refugees }\end{array}$ & $\begin{array}{l}\text { Asylum } \\
\text { refugees }\end{array}$ & $\begin{array}{l}\text { Family reunion } \\
\text { migrants }\end{array}$ & \\
\hline Iraq & 293 & 1925 & 413 & 336 & 380 & 637 & 3984 \\
\hline Somalia & 56 & 880 & 533 & 69 & 651 & 760 & 2949 \\
\hline Afghanistan & 298 & 512 & 299 & 509 & 216 & 312 & 2146 \\
\hline Iran & 406 & 290 & 200 & 368 & 166 & 370 & 1800 \\
\hline Myanmar & 361 & 25 & 12 & 343 & 12 & 31 & 784 \\
\hline $\begin{array}{l}\text { D.Rep. of } \\
\text { Congo }\end{array}$ & 128 & 65 & 50 & 212 & 78 & 89 & 622 \\
\hline Syria & 104 & 226 & 34 & 83 & 85 & 65 & 597 \\
\hline Sudan & 246 & 17 & 14 & 182 & $<10$ & 42 & $501+$ \\
\hline Ethiopia & 26 & 20 & 63 & 41 & 56 & 124 & 330 \\
\hline Sri Lanka & 39 & 54 & 38 & 21 & 20 & 122 & 294 \\
\hline $\begin{array}{l}\text { Form. } \\
\text { Yugoslavia }\end{array}$ & $<10$ & 62 & 32 & $<10$ & 65 & 70 & $229+$ \\
\hline Lebanon & $<10$ & 10 & 14 & $<10$ & $<10$ & 34 & $58+$ \\
\hline Rwanda & $<10$ & 14 & 13 & $<10$ & 18 & 11 & $56+$ \\
\hline Cambodia & $<10$ & $<10$ & 16 & 13 & $<10$ & 23 & $52+$ \\
\hline Eritrea & 32 & $<10$ & $<10$ & $<10$ & $<10$ & $<10$ & $32+$ \\
\hline Congo & 12 & $<10$ & $<10$ & 16 & $<10$ & $<10$ & $28+$ \\
\hline Liberia & 13 & $<10$ & $<10$ & 15 & $<10$ & $<10$ & $28+$ \\
\hline Saudi Arabia & $<10$ & $<10$ & $<10$ & $<10$ & $<10$ & 12 & $12+$ \\
\hline Côte d'Ivoire & 11 & $<10$ & $<10$ & $<10$ & $<10$ & $<10$ & $11+$ \\
\hline Burundi & $<10$ & $<10$ & $<10$ & $<10$ & $<10$ & $<10$ & $0+$ \\
\hline Kuwait & $<10$ & $<10$ & $<10$ & $<10$ & $<10$ & $<10$ & $0+$ \\
\hline
\end{tabular}


Table 3 Regression coefficients of the control variables

\begin{tabular}{|c|c|c|c|c|c|c|c|c|c|c|}
\hline \multirow{3}{*}{$\begin{array}{l}\text { Variable } \\
\text { Local unemployment rate }(0-100)\end{array}$} & \multicolumn{4}{|c|}{$\begin{array}{l}\text { Earnings } \\
\text { (EUR per year) }\end{array}$} & \multicolumn{4}{|c|}{$\begin{array}{l}\text { Unemployment rate } \\
(0-100)\end{array}$} & \multirow{2}{*}{\multicolumn{2}{|c|}{$\begin{array}{l}\text { Childcare rate } \\
(0-100) \\
\text { Females }\end{array}$}} \\
\hline & \multicolumn{2}{|l|}{ Males } & \multicolumn{2}{|l|}{ Females } & \multicolumn{2}{|c|}{ Males } & \multicolumn{2}{|c|}{ Females } & & \\
\hline & -225 & $* * *$ & -79 & $* * *$ & 0.6 & $* * *$ & 0.8 & $* * *$ & -0.3 & $* * *$ \\
\hline Age & 574 & $* * *$ & 75 & & -0.7 & & 0.9 & * & -0.8 & * \\
\hline Age $\wedge 2$ & -9 & $* * *$ & -1 & * & 0.0 & $* *$ & 0.0 & & 0.0 & \\
\hline \multicolumn{11}{|l|}{ Admission category (ref. resettled refugee) } \\
\hline Asylum refugee & 1481 & & -336 & & -5 & & -4.9 & & 4.6 & \\
\hline Family reunion & 186 & & 234 & & -0 & & -9.2 & $* * *$ & 16 & $* * *$ \\
\hline Years of residence & 764 & * & -608 & $* * *$ & -2 & & 3.4 & $* *$ & 1.3 & \\
\hline Years of residence^${ }^{\wedge}$ & 150 & $* *$ & 247 & $* * *$ & -1 & $* *$ & -1.3 & $* * *$ & -0.2 & \\
\hline Years of residence $\wedge 3$ & -9 & $* * *$ & -11 & $* * *$ & 0.0 & $* *$ & 0.1 & $* * *$ & 0.0 & \\
\hline \multicolumn{11}{|c|}{ Admiss. cat. (ref. resettled) ${ }^{*}$ years of residence } \\
\hline Years of residence ${ }^{*}$ asylum refugee & 316 & & 937 & $* * *$ & 0.8 & & -1.8 & & -1.2 & \\
\hline Years of residence * family reunion & 1036 & * & 690 & ** & -3.0 & & -5.9 & $* * *$ & -6.1 & $* * *$ \\
\hline Years of residence $\wedge 2 *$ asylum refugee & -103 & & -173 & $* * *$ & -0 & & 0.4 & & 0.2 & \\
\hline Years of residence $\wedge 2 *$ family reunion & -123 & & -180 & $* * *$ & 0.4 & & 1.6 & $* * *$ & 0.9 & $* * *$ \\
\hline Years of residence $\wedge 3 *$ asylum refugee & 4.8 & & 6.9 & $* *$ & 0.0 & & 0.0 & & 0.0 & \\
\hline Years of residence $\wedge 3 *$ family reunion & 3.8 & & 8.3 & ** & 0.0 & & -0.1 & $* * *$ & 0.0 & $* * *$ \\
\hline No. of children, 0-3 years & 4 & & -1185 & $* * *$ & 1.0 & * & -25.8 & $* * *$ & 42.5 & $* * *$ \\
\hline No. of children, $4-7$ years & -424 & $* * *$ & -774 & $* * *$ & 1.0 & * & 1.0 & * & 0.3 & \\
\hline Single parent $(0 / 1)$ & -286 & & -766 & $* * *$ & -2.7 & $* *$ & 3.8 & $* * *$ & -3.9 & $* * *$ \\
\hline \multicolumn{11}{|l|}{ Migration year (ref. 2001) } \\
\hline 2002 & 2474 & $* *$ & -57 & & -2.8 & & -1.0 & & -0.8 & \\
\hline 2003 & 1413 & * & -519 & & -1.2 & & 0.0 & & 1.3 & \\
\hline 2004 & 1562 & & 38 & & 0.1 & & -2.6 & & -0.1 & \\
\hline 2005 & 1316 & & -309 & & -0.1 & & 0.1 & & 1.0 & \\
\hline 2006 & 1101 & & 570 & & 3.3 & & -0.9 & & 0.7 & \\
\hline 2007 & 20 & & 52 & & 5.2 & * & -0.2 & & -0.4 & \\
\hline 2008 & 266 & & -322 & & 5.1 & * & 0.4 & & 0.2 & \\
\hline 2009 & -996 & & -152 & & 7.8 & $* * *$ & 1.4 & & 2.0 & \\
\hline 2010 & -590 & & -22 & & 5.4 & * & 2.6 & & 0.6 & \\
\hline 2011 & -338 & & 29 & & 3.5 & & 1.9 & & 0.2 & \\
\hline 2012 & -567 & & 92 & & 5.5 & $*$ & -1.3 & & 1.1 & \\
\hline 2013 & 214 & & 350 & & 3.4 & & -1.9 & & 0.4 & \\
\hline 2014 & -62 & & 320 & & 5.9 & * & 3.9 & & -0.1 & \\
\hline Origin country dummies (21) & $x$ & & $x$ & & $x$ & & $x$ & & $x$ & \\
\hline
\end{tabular}

${ }^{*} p<0,05,{ }^{* *} p<0,01,{ }^{* * *} p<0,001$ 


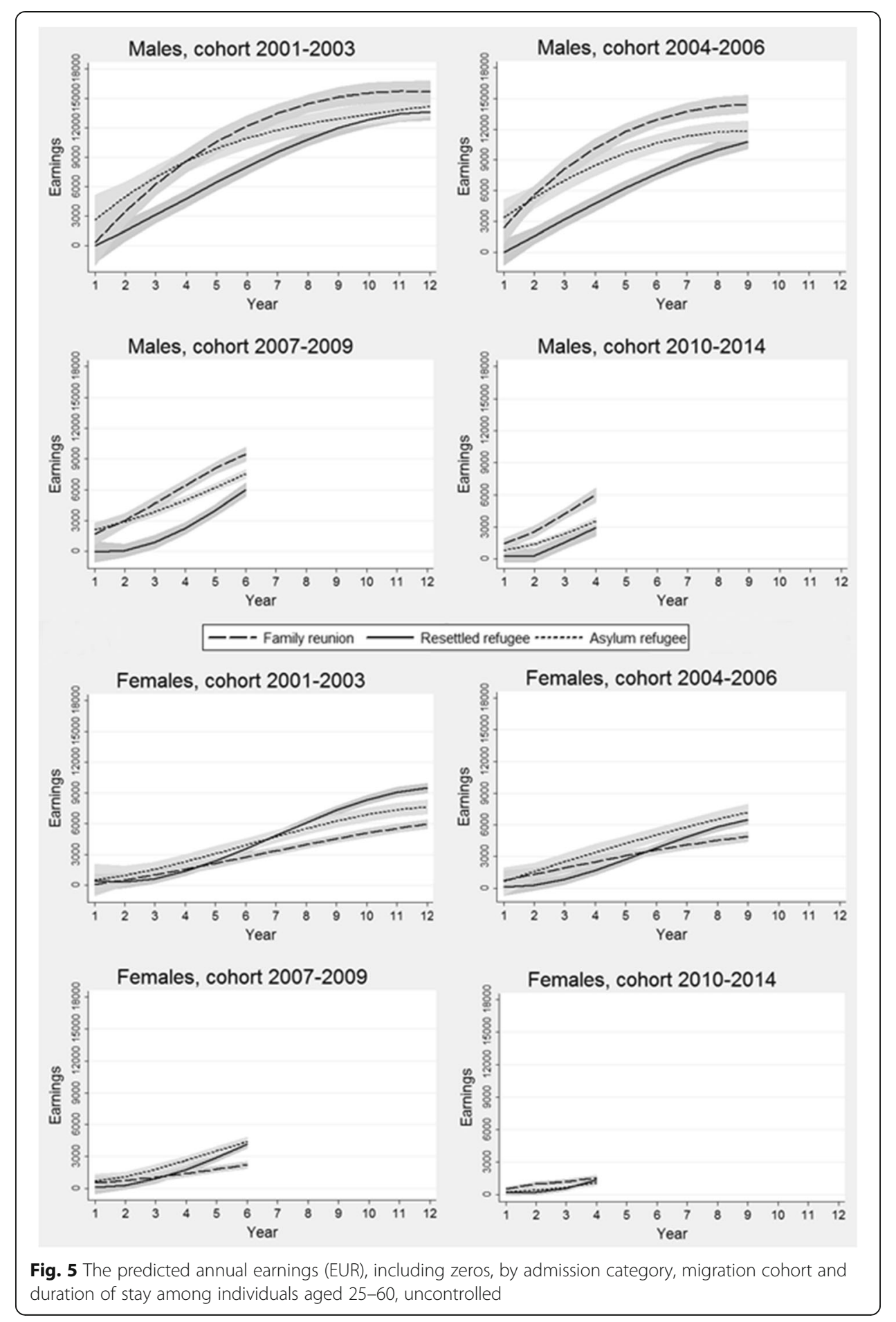




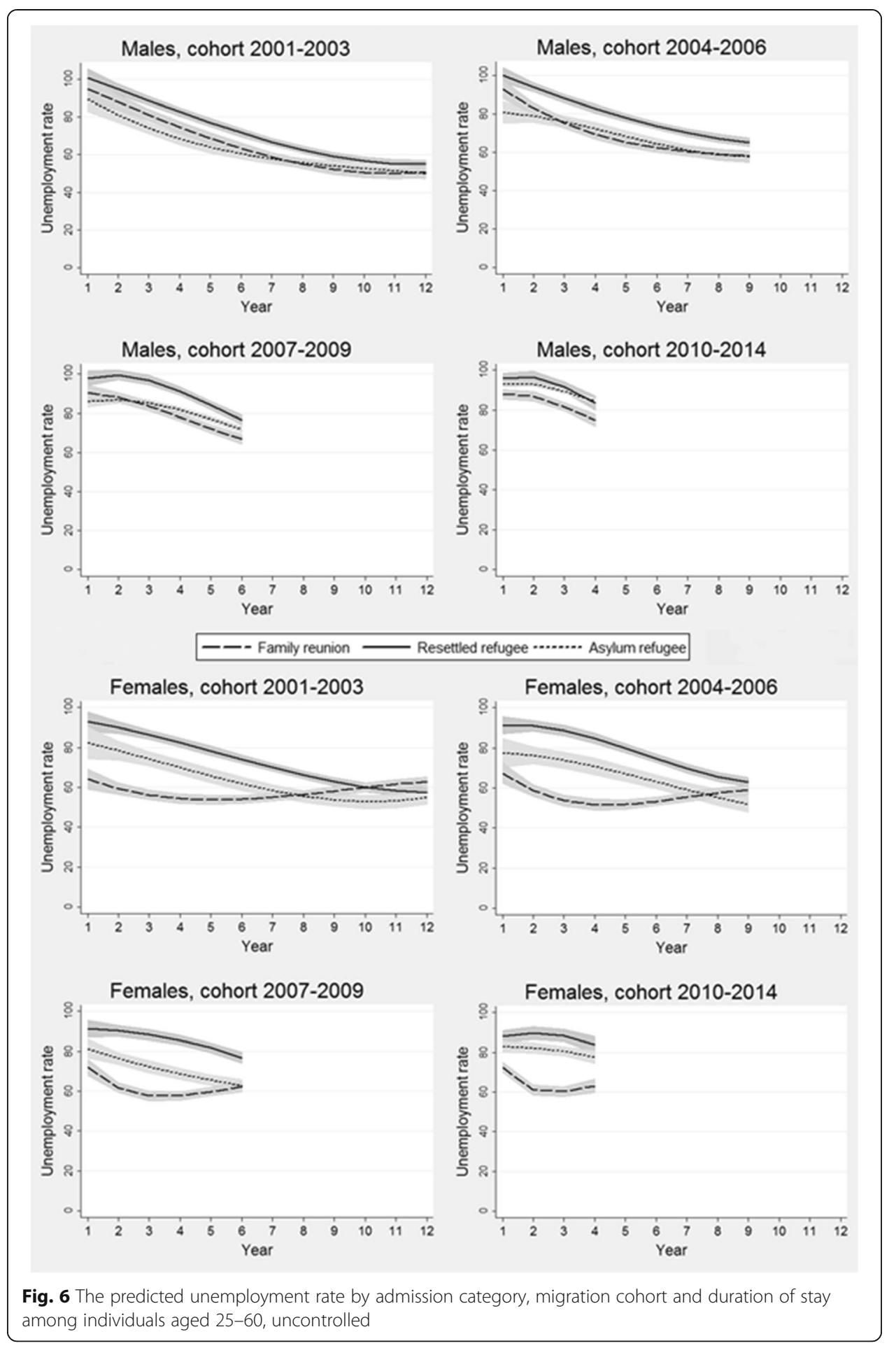




\section{Acknowledgements}

I state my gratitude for the useful comments to Dr. Signe Jauhiainen, Professor Matti Sarvimäki, Dr. Riikka Savolainen and the participants of the TITA seminar in Turku in June 2017.

\section{Author's contributions}

JT is responsible for compiling the research data, designing and carrying out the analysis and writing the manuscript. The author read and approved the final manuscript.

\section{Funding}

This research was financially supported by the Strategic Research Council of the Academy of Finland (nr. 293103).

\section{Availability of data and materials}

Micro-level research data is available only for those possessing valid data licenses from the Social Insurance Institution of Finland (Kela). https://www.kela.fi/web/en/research-data-requests

\section{Ethics approval and consent to participate}

Not applicable.

\section{Consent for publication}

Not applicable.

\section{Competing interests}

The author declares that he has no competing interests.

Received: 26 November 2019 Accepted: 18 May 2020

Published online: 11 August 2020

\section{References}

Aguilera, M. B., \& Massey, D. S. (2003). Social capital and the wages of Mexican migrants: New hypotheses and tests. Social Forces, 82(2), 671-701.

Ahlgren-Leinvuo, H. (2005). Pakolaiset Suomen kunnissa - Kuntapaikasta pääkaupunkiseudulle [Refugees in Finnish municipalities - from the initial location to the capital area]. In T. Joronen (Ed.), Maahanmuuttajien elinolot pääkaupunkiseudulla (pp. 25-45). Helsinki: City of Helsinki Urban Facts.

Ahmad, A. (2015). "Since many of my friends were working in the restaurant": The dual role of immigrants' social networks in occupational attainment in the Finnish labour market. Journal of International Migration and Integration, 16(4), 965-985.

Aksoy, C.G., \& Poutvaara, P. (2019). Refugees' and irregular migrants' self-selection into Europe: Who migrates where? (CESifo Working Paper No. 7781).

Andersson, G. (2004). Childbearing after migration: Fertility patterns of foreign-born women in Sweden. International Migration Review, 38(2), 747-774.

Antecol, H. (2000). An examination of cross-country differences in the gender gap in labor force participation rates. Labour Economics, 7(4), 409-426.

Åslund, O., \& Rooth, D. (2007). Do when and where matter? Initial labour market conditions and immigrant earnings. The Economic Journal, 518(117), 422-448.

Barrett, A., \& McCarthy, Y. (2008). Immigrants and welfare programmes: Exploring the interactions between immigrant characteristics, immigrant welfare dependence, and welfare policy. Oxford Review of Economic Policy, 3(24), 542-559.

Bevelander, P. (2011). The employment integration of resettled refugees, asylum claimants, and family Reunion migrants in Sweden. Refugee Survey Quarterly, 1(30), 22-43.

Bevelander, P., \& Pendakur, R. (2009). The employment attachment of resettled refugees and family Reunion migrants in Sweden. In P. Bevelander, M. Hagström, \& S. Rönnqvist (Eds.), Resettled and included? The employment integration of resettled refugees in Sweden (pp. 227-246). Malmö: Malmö University.

Bevelander, P., \& Pendakur, R. (2014). The labour market integration of refugee and family Reunion immigrants: A comparison of outcomes in Canada and Sweden. Journal of Ethnic and Migration Studies, 5(40), 689-709.

Birgier, D. P., Lundh, C., Haberfeld, Y., \& Elldér, E. (2016). Self-selection and host country context in the economic assimilation of political refugees in the United States, Sweden, and Israel. International Migration Review. https://doi.org/10.1111/imre. 12309 .

Boccagni, P., \& Baldassar, L. (2015). Emotions on the move: Mapping the emergent field of emotion and migration. Emotion, Space and Society, 16, 73-80.

Borjas, G. J. (1985). Assimilation, changes in cohort quality, and the earnings of immigrants. Journal of Labor Economics, 3(4), 463-489.

Borjas, G. J. (1987). Self-selection and the earnings of immigrants. The American Economic Review, 4(77), 531-553.

Borjas, G. J. (1999). Immigration and welfare magnets. Journal of Labor Economics, 4(17), 607-637.

Bratsberg, B., Raaum, O., \& Røed, K. (2016). Labour market integration of refugees in Norway. In F. Fasani (Ed.), Refugees and economic migrants: Facts, policies and challenges (pp. 37-54). London: CEPR Press.

Busk, H., Jauhiainen, S., Kekäläinen, A., Nivalainen, S., \& Tähtinen, T. (2016). Maahanmuuttajat työmarkkinoilla: tutkimus eri vuosina Suomeen muuttaneiden työurista [Immigrants in labor markets - a study of immigrants with different arrival years]. Helsinki: Finnish Centre for Pensions.

Cerrutti, M., \& Massey, D. S. (2001). On the auspices of female migration from Mexico to the United States. Demography, 38(2), $187-200$. 
Damm, A. P., \& Rosholm, M. (2010). Employment effects of spatial dispersal of refugees. Review of Economics of the Household, $1(8), 105-146$

Dustmann, C., \& Görlach, J. (2016). The economics of temporary migrations. Journal of Economic Literature, 1(54), 98-136.

Duvander, A., \& Ellingsæter, A. L. (2016). Cash for childcare schemes in the Nordic welfare states: Diverse paths, diverse outcomes. European Societies, 1(18), 70-90.

Edin, P., LaLonde, R., \& Åslund, O. (2000). Emigration of immigrants and measures of immigrant assimilation: Evidence from Sweden. Swedish Economic Policy Review, 7, 163-204.

Eurostat. (2016). Asylum quarterly report. http://ec.europa.eu/eurostat/statistics-explained/index.php/Asylum_quarterly_report. Accessed 12 July 2018.

Eurostat. (2020). Activity rates by sex, age and country of birth (\%). http://appsso.eurostat.ec.europa.eu/nui/show.do?dataset= Ifsa_argacob. Accessed 4 Mar 2020.

Finnish Immigration Service. (2016). Humanitarian protection no longer granted; new guidelines issued for Afghanistan, Iraq and Somalia. https://migrifi/en/article/-/asset_publisher/humanitaarista-suojelua-ei-myonneta-enaa-uudet-maalinjauksetafganistanista-irakista-ja-somaliasta. Accessed 2 Mar 2020.

Finnish Immigration Service. (2018). Quota refugees. http://migrifi/en/quota-refugees. Accessed 2 Apr 2019.

Finnish Immigration Service. (2019). Old statistics on asylum and refugees. https://migrifi/en/old-statistics. Accessed 3 Mar 2020.

Finnish Ministry of Interior. (2020). Resettlement of quota refugees is one way of helping the most vulnerable. https:// intermin.fi/en/areas-of-expertise/migration/refugees-and-asylum-seekers/quota-refugees. Accessed 29 May 2020

Greenwell, L., Valdez, R. B., \& DaVanzo, J. (1997). Social ties, wages, and gender in a study of Salvadorean and Pilipino immigrants in Los Angeles. Social Science Quarterly, 2(78), 559-577.

Hainmueller, J., Hangartner, D., \& Lawrence, D. (2016). When lives are put on hold: Lengthy asylum processes decrease employment among refugees. Science Advances. https://doi.org/10.1126/sciadv.1600432.

Hatton, T. J. (2017). Refugees and asylum seekers, the crisis in Europe and the future of policy. Economic Policy, 32(91), 447496.

Jarman, J., Blackburn, R. M., \& Racko, G. (2012). The dimensions of occupational gender segregation in industrial countries. Sociology, 46(6), 1003-1019.

Jauhiainen, J. (2017). Turvapaikka Suomesta? Vuoden 2015 turvapaikanhakijat ja turvapaikkaprosessit Suomessa [Asylum in Finland? The 2015 asylum seekers and the asylum processes in Finland]. Turun yliopiston maantieteen ja geologian laitoksen julkaisuja 5. Turku: Turku University.

Kahn, L. M. (2012). Labor market policy: A comparative view on the costs and benefits of labor market flexibility. Journal of Policy Analysis and Management, 37(1), 94-110.

Lancee, B. (2010). The economic returns of immigrants' bonding and bridging social capital: The case of the Netherlands. International Migration Review, 44(1), 202-226.

Liebkind, K., Larja, L., \& Brylka, A. (2016). Ethnic and gender discrimination in recruitment: Experimental evidence from Finland. Journal of Social and Political Psychology, 4(1), 403-426.

Lundberg, S., \& Rose, E. (2000). Parenthood and the earnings of married men and women. Labour Economics, 6(7), 689-710.

Lunneblad, J. (2017). Integration of refugee children and their families in the Swedish preschool: Strategies, objectives and standards. European Early Childhood Education Research Journal, 25(3), 359-369.

Monti, A. (2019). Re-emigration of foreign-born residents from Sweden: 1990-2015. Population, Space and Place. https://doi. org/10.1002/psp.2285.

Mussino, E., \& Strozza, S. (2012). The fertility of immigrants after arrival: The Italian case. Demographic Research, 26, 99-130.

OECD (2017). Who bears the cost of integrating refugees? Migration policy debates 13. Paris: OECD.

Pehkonen, A. (2006). Immigrants paths to employment in Finland. Finnish Yearbook of Population Research, $42,113-128$.

Portes, A., \& Sensenbrenner, J. (1993). Embeddedness and immigration: Notes on the social determinants of economic action American Journal of Sociology, 98(6), 1320-1350.

Saarela, J., \& Weber, R. (2017). Assessment of educational misclassification in register-based data on Finnish immigrants in Sweden. Scandinavian Journal of Public Health, 17(45), 20-24.

Sainsbury, D. (2006). Immigrants social rights in comparative perspective: Welfare regimes, forms in immigration and immigration policy regimes. Journal of European Social Policy, 3(16), 229-244.

Sarvimäki, M. (2017). Labor market integration of refugees in Finland. VATT research reports 185. Helsinki: VATT.

Sarvimäki, M., \& Hämäläinen, K. (2016). Integrating immigrants: The impact of restructuring ALMP. Journal of Labor Economics, 2(34), 479-508.

Schneider, F., \& Kearney, A. T. (2013). The shadow economy in Europe. Linz: Johannes Kepler Universitat.

Sjöblom-Immala, H. (2016). Katsaus somalialaisten, irakilaisten ja afganistanilaisten maan sisäiseen muuttoliikkeeseen Suomessa 2000-luvulla [The internal mobility of Somalis, Iraqis and Afghans in Finland during the 2000s]. TEM reports 27. Helsinki: Ministry of Labor.

Statistics Finland. (2016). Population structure. http://stat.fi/til/vaerak/tau_en.html. Accessed 12 July 2016.

Statistics Finland (2018). Sukupuolten tasa-arvo Suomessa 2018 [Gender equality in Finland 2018]. Helsinki: Statistics Finland.

Statistics Finland. (2019a). Labour force survey. https://www.stat.fi/til/tyti/index_en.html. Accessed 29 Mar 2019.

Statistics Finland. (2019b). Index of wage and salary earnings. http://www.stat.fi/til/ati/index_en.html. Accessed 29 Mar 2019.

Tervola, J. (2015). Maahanmuuttajien kotihoidon tuen käyttö 2000-luvulla [Use of child home care allowance among immigrants in Finland during the 2000s]. Yhteiskuntapolitiikka, 2(80), 121-133.

Tervola, J., Duvander, A., \& Mussino, E. (2017). Promoting parental leave for immigrant fathers—What role does policy play? Social Politics: International Studies in Gender, State \& Society, 3(24), 269-297.

UNHCR. (2018). Convention and protocol relating to the status of refugees. http://www.unhcr.org/3b66c2aa10. Accessed 20 Mar 2018. 
Välimäki, M. (2019). Kylmän sodan ajasta eurooppalaiseen päätöksentekoon: kansainvälistä suojelua hakevia ihmisiä koskeva politiikka ja lainsäädäntö 1973-2015. The politics and legislation of international protection during 19732015]. In E. Lyytinen (Ed.), Turvapaikanhaku ja Pakolaisuus Suomessa (pp. 39-64). Turku: Migration Institute of Finland.

Vasta, E. (2004). Informal employment and immigrant networks: A review paper. Centre on migration, policy and society working paper 2. Oxford: University of Oxford.

Zontini, E. (2010). Enabling and constraining aspects of social capital in migrant families: Ethnicity, gender and generation. Ethnic and Racial Studies, 33(5), 816-831.

\section{Publisher's Note}

Springer Nature remains neutral with regard to jurisdictional claims in published maps and institutional affiliations.

Submit your manuscript to a SpringerOpen ${ }^{\circ}$ journal and benefit from:

- Convenient online submission

- Rigorous peer review

- Open access: articles freely available online

High visibility within the field

- Retaining the copyright to your article

Submit your next manuscript at $\boldsymbol{\nabla}$ springeropen.com 